Seven renal abnormalities were diagnosed that had not been detected antenatally. Only one of the seven mothers had not attended for any scans; in the others the abnormality had not been found in appropriate scans. Four of these patients had vesicoureteric reflux, which is known to be difficult to diagnose antenatally. ${ }^{4}$

The impact that early diagnosis of abnormalities of the fetal renal tract and subsequent intervention may have on the incidence of symptomatic renal disease later in life-for example, acute pyelonephritis and recurrent urinary tract infection-remains unknown. We also do not know what proportion of those in whom a renal abnormality was diagnosed antenatally would have suffered renal scarring or deterioration of renal function had the diagnosis been delayed until after a urinary tract infection. To obtain this information would require an untreated control group, which would not be ethical. We intend, however, to reassess this cohort of children at age 5 years to determine the incidence of renal disease.

We found a high incidence of renal abnormalities in this study and conclude that antenatal ultrasonography at 28 weeks' gestation is an effective method of screening for structural renal abnormality.

We thank Dr S A Price and the staff of the ultrasonography department for their help in collecting data.

Turnock RR, Shawis R. Management of fetal urinary tract abnormalities detected by prenatal ultrasonography. Arch Dis Child 1984;59:962-5.

Smith D, Egginton JA, Brookfield DSK. Detection of abnormality of feta urinary tract as a predictor of renal tract disease. Br Med $\mathcal{F} 1987 ; 294: 27-8$.

Madarikan BA, Hayward C, Roberts GM, Lari J. Clinical outcome of feta uropathy. Arch Dis Child 1988;63:961-3.

Ring E, Zobel G. Urinary infection and malformations of urinary tract in infancy. Arch Dis Child 1988;63:818-20."

Helin I, Persson P-H. Prenatal diagnosis of urinary tract abnormalities by ultrasound. Pediatrics 1986;78:879-83.

6 Pocock RD, Witcombe JB, Andrews HS, Berry PJ, Frank JD. The outcome of antenatally diagnosed urological abnormalities. Br f Urol 1985;57:788-92. antenatally diagnosed urological abnormalities. $B r \mathcal{F}$ Urol $1985 ; 57: 788-92$.
Grignon A, Filion R, Filiatrault $\mathrm{D}$, et al. Urinary tract dilatation in utero: Grignon A, Filion R, Filiatrault D, et al. Urinary tract dilatation
classification and clinical applications. Radiology 1986;160:645-7.

classification and clinical applications. Radiology 1986;160:645-7.
Watson AR, Readett D, Nelson CS, Kapila L, Mayell MJ. Dilemmas associated with antenatally detected urinary tract abnormality. Arch $D i$ Child 1988;63:719-22.

Thomas DFM, Irving HC, Arthur RJ. Pre-natal diagnosis: how useful is it? Brf Urol 1985;57:784-7.

10 Furness ME. Reporting obstetric ultrasound. Lancet 1987;i:675-6.

(Accepted 9 March 1989)

\title{
Clinical and laboratory studies of arthritis in leprosy
}

\author{
S L Atkin, A El-Ghobarey, M Kamel, J P Owen, W C Dick
}

\begin{abstract}
Arthritis associated with leprosy is underreported. In Egypt 66 patients from a leprosy colony were studied, 20 of whom had arthropathy. This was characterised by an inflammatory symmetrical peripheral polyarthritis. The wrist, metacarpal and proximal interphalangeal joints of the hands, the knees, and the metatarsophalangeal joints of the feet were affected with associated morning stiffness. The arthritis was erosive in 11 out of 20 patients, had no features of the arthritis associated with erythema nodosum leprosum reactions, but symptomatically responded to antileprosy treatment.

This arthritis would seem to be a previously unrecognised feature of leprosy.
\end{abstract}

\section{Introduction}

Leprosy is caused by the obligate intracellular parasite Mycobacterium leprae.' Considerable attention has been devoted to the dermal, neural, and osseous complications of leprosy ${ }^{2}$ but little to those of the synovial joint, apart from the arthritis associated with erythema nodosum leprosum ${ }^{3.5}$ and the well recognised Charcot's joint. In two large scale studies from India musculoskeletal problems were found in some patients with leprosy, but no detailed information was given. ${ }^{67}$ We have reported a peripheral, deforming polyarthritis in patients with leprosy in the absence of erythema nodosum leprosum in Papua New Guinea, but no radiological examinations or follow up were performed. ${ }^{8}$

We examined patients with active leprosy in Egypt, putting particular emphasis on the clinical and radiological features of the synovial joints.

\section{Abou Zabel Leprosy}

Colony, Kaloubya, Egypt A El-Ghobarey, MRCP, professor of rheumatology

$M$ Kamel, MD, professor of

haematology and immunology

Correspondence to: $\mathrm{Dr}$ Dick.

BrMed f 1989;298:1423-5
All patients from the Abou Zabel leprosy colony in Egypt attending the medical clinic to receive supplies of their antileprosy treatment were asked to participate in this study. Sixty six consecutive volunteers (44 men and 22 women; mean (SE) age $34 \cdot 3(15 \cdot 4)$ years; mean duration of the disease $8.5(2 \cdot 8)$ years) participated in the study and all gave informed consent. Patients with Charcot's arthropathy or any clinical neurological abnormality were excluded. The diagnosis of leprosy was confirmed in each case from skin smears and biopsy specimens and classified according to the method of Ridley and Jopling.

A detailed history was taken of peripheral articular disease, particular attention being paid to a personal or family history of any of the codiseases of seronegative spondarthritides. ${ }^{9}$ Any history of stiffness or pain was graded and a functional index of musculoskeletal impairment completed. ${ }^{10}$ The pattern of development of the articular symptoms was plotted, and in all patients the Ritchie articular index was scored." Haemoglobin concentration, white cell count, and erythrocyte sedimentation rate were measured at the clinical examination. The history and examination, microscopy of urine and stools, and rectal biopsy were used to exclude schistosomiasis and infection with yersinia and Gram negative enteropathic bacteria. Hepatitis B and syphilis were excluded serologically.

Patients with lepromatous leprosy were initially treated with rifampicin (600 $\mathrm{mg}$ once daily) and clofazimine ( $100 \mathrm{mg}$ once daily) for four weeks followed by dapsone (100 mg once daily) and clofazimine ( 100 $\mathrm{mg}$ thrice weekly) for life thereafter; patients with borderline and borderline lepromatous leprosy were treated with rifampicin (600 $\mathrm{mg}$ once daily) and clofazimine (100 mg once daily) for one week and dapsone (100 mg once daily) for life thereafter; and patients with borderline tuberculoid and tuberculoid leprosy were treated with only dapsone (100 mg once daily) for two years.

Standard radiographs were taken of the hands, feet, and knees and were assessed by one radiologist (JPO), who did not know the clinical and laboratory results. Only those patients with arthritis underwent radiography. Serum was separated and aliquots were transported to England in dry ice. IgM rheumatoid factor, ${ }^{12}$ $\alpha_{1}$ acid glycoprotein, $\alpha_{2}$ macroglobulin, ${ }^{13}$ and $C$ reactive protein ${ }^{14}$ concentrations were determined by established methods. 
Non-parametric tests were used to compare data among the clinical groups. ${ }^{15}$

Results

CLINICAL FEATURES

Twenty patients had a symmetrical inflammatory peripheral polyarthritis (table I). This had developed from eight months to seven years after the onset of the first symptoms of leprosy and independently of erythema nodosum leprosum or lepra type 1 reactions. The onset was insidious with a pattern of exacerbations and remissions. The joints affected were those of the wrist, the metacarpal and proximal interphalangeal joints of the hands, the knees, and the metatarsophalangeal joints of the feet. Morning stiffness lasted for between 30 minutes and one hour and stiffness after inactivity varied from 10 to 15 minutes. All patients had swollen joints with effusions and synovial swelling, tenderness over the articular margin (Ritchie index 8 to 66), and pain on both active and passive movements in all directions and planes of movement. No patient had subcutaneous or tendinous nodules. No patient with lepromatous leprosy had the skin lesions of erythema nodosum leprosum, and no patient with borderline leprosy or tuberculoid leprosy had peripheral skin lesions.

This inflammatory polyarthritis invariably responded poorly to non-steroidal anti-inflammatory agents. A gradual resolution of the articular signs and symptoms and a decrease in the duration and severity of exacerbations seemed to be associated with the resumption of antileprosy treatment, which had often been either stopped or taken intermittently (fig). The symptoms and signs of the arthritis never resolved completely between acute episodes, and all patients had a degree of morning stiffness and painful joints. In some permanent structural deformities such as swan

TABLE I-Details of 20 Egyptian patients with leprosy (excluding erythema nodosum leprosum) and symmetrical peripheral inflammatory arthritis

\begin{tabular}{lcccc}
\hline Type of leprosy & $\begin{array}{c}\text { No of } \\
\text { patients }\end{array}$ & $\begin{array}{c}\text { Sex } \\
\text { (men:women) }\end{array}$ & $\begin{array}{c}\text { Mean(SE) age } \\
\text { (years) }\end{array}$ & $\begin{array}{c}\text { Mean (SE) duration of } \\
\text { disease (years) }\end{array}$ \\
\hline Lepromatous & 13 & $8: 5$ & $35 \cdot 9(3 \cdot 5)$ & $7 \cdot 4(3 \cdot 2)$ \\
Borderline lepromatous & 3 & $2: 1$ & $22,24,16$ & $2,1,1$ \\
Borderline & 2 & $1: 1$ & 20,24 & 6 months, \\
Borderline tuberculoid & 2 & $2: 0$ & 22,30 & 1,15
\end{tabular}

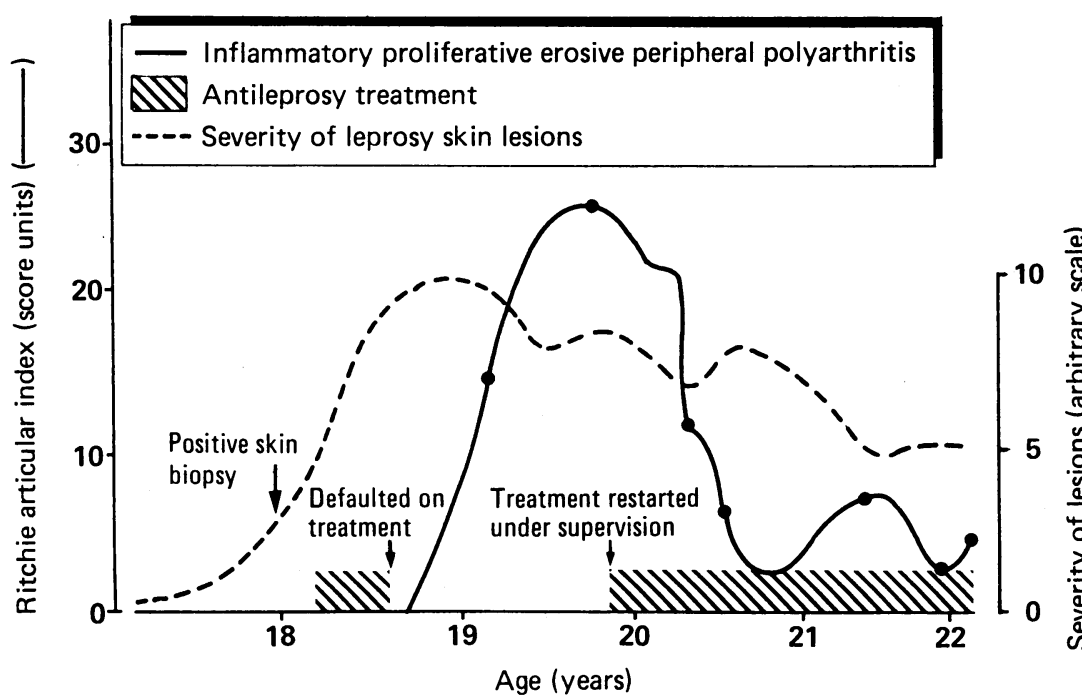

Development of peripheral symmetrical polyarthritis in man aged 22 with active borderline tuberculoid leprosy and its response to antileprosy treatment. Arthritis developed two years after the onset of leprosy, during which time he had intermittently taken treatment. Proximal interphalangeal, metacarpophalangeal (with radiological juxta-articular erosions), wrist, and ankle joints were affected. After reintroduction of antileprosy treatment the Ritchie articular index fell and the duration of morning stiffness and stiffness after inactivity decreased. IgM rheumatoid factor was not detected in his serum neck and boutonnière deformity and trigger finger were noted.

Thirteen patients had an erythema nodosum leprosum reaction, and all had an inflammatory polyarthritis affecting distal and proximal joints. In 12 patients the polyarthritis and clinical features resolved leaving no residual disability or deformity. In the other patient, who already had erosive inflammatory polyarthritis, the acute changes resolved leaving the joints as they had been before the reaction.

Thirty three patients did not have arthritis.

\section{RADIOLOGICAL RESULTS}

Of the 33 patients with arthritis, 28 underwent radiography: eight had an erythema nodosum leprosum reaction and 20 the symmetrical polyarthritis described above (table II). Osteolysis typical of the changes well documented in leprosy ${ }^{4}{ }^{16}$ was seen in the hands and feet of the patients, none of whom had an erythema nodosum leprosum reaction.

Juxta-articular erosions were seen in the carpal bones and the metacarpal and proximal interphalangeal joints of 12 patients (11 with polyarthritis and one with an erythema nodosum leprosum reaction) and additionally in the metatarsophalangeal joints of four. All patients with radiological erosive articular disease had pronounced clinical signs of inflammation of the joints. Neither the site nor the extent of the erosions correlated with the type of leprosy.

\section{LABORATORY RESULTS}

C Reactive protein concentrations were significantly raised (table III) in the patients with arthritis and in those with erythema nodosum leprosum reactions compared with those without arthritis $(p \leqslant 0.04$ and $p \leqslant 0.01$, respectively). $\alpha_{1}$ Acid glycoprotein and $\alpha_{2}$ macroglobulin concentrations did not differ between the patients with and without arthritis and those with erythema nodosum leprosum reactions. There was no significant relation between the Ritchie index and any of the acute phase protein concentrations. Table IV summarises the results of Rose-Waaler tests to detect the presence of $\operatorname{IgM}$ rheumatoid factor.

TABLE II-Summary of radiological findings in 28 patients with arthritis ${ }^{\star}$

\begin{tabular}{lcc}
\hline Type of leprosy & $\begin{array}{c}\text { Bone erosion present } \\
(\mathbf{n}=12)\end{array}$ & $\begin{array}{c}\text { Bone erosion absent } \\
(\mathbf{n}=16)\end{array}$ \\
\hline Lepromatous leprosy & 8 & 5 \\
Borderline lepromatous & 2 & 1 \\
Borderline & 1 & 2 \\
Borderline tuberculoid & 1 & 1 \\
Erythema nodosum leprosum & 7 \\
\hline
\end{tabular}

* Radiographs of five patients were not good enough to use.

\section{Discussion}

The symmetrical peripheral inflammatory erosive polyarthritis reported here does not correspond to any description of arthritis in patients with leprosy. ${ }^{3.7} \mathrm{We}$ have reported a similar arthritis in patients in Papua New Guinea, though no radiological examinations or follow up were performed. ${ }^{8}$ In 12 patients juxtaarticular erosions marked the presence of underlying bone destruction, a feature that has not been reported before, though severe joint osteoporosis has been described. ${ }^{4}$ This destructive inflammatory polyarthritis did not differ in its clinical presentation or development within any subgroup of leprosy. We could not distinguish clinically between patients with and without radiological erosions or determine whether the disease in patients without erosions would have progressed to a destructive stage.

Whenever antileprosy treatment was introduced the 
TABLE III - Mean (SE) concentrations of acute phase proteins in patients with and without arthritis and in patients with erythema nodosum leprosum

\begin{tabular}{lccc}
\hline & $\begin{array}{c}\text { C Reactive protein } \\
(\mathrm{mg} / \mathrm{l})\end{array}$ & $\begin{array}{c}\alpha_{1} \text { Acid glycoprotein } \\
(\mathrm{mg} / \mathrm{l})\end{array}$ & $\begin{array}{c}\alpha_{2} \text { Macroglobulin } \\
(\mathrm{mg} / \mathrm{l})\end{array}$ \\
\hline Leprosy $(\mathrm{n}=30)$ & $15 \cdot 0(4 \cdot 5)$ & $823(65)$ & $2788(170)$ \\
Leprosy with arthritis $(\mathrm{n}=20)$ & $26 \cdot 4(8 \cdot 8)^{\star}$ & $918(70)$ & $2429(93)$ \\
Erythema nodosum leprosum $(\mathrm{n}=13)$ & $61 \cdot 1(23 \cdot 6) \dagger$ & $1091(160)$ & $2297(147)$ \\
\hline
\end{tabular}

${ }^{\star} p \leqslant 0.04 . \quad \quad t p \leqslant 0 \cdot 01$.

TABLE IV - Results of Rose-Waaler tests in patients with and without arthritis and in patients with erythema nodosum leprosum reactions

\begin{tabular}{lccc}
\hline Titre & $\begin{array}{c}\text { Patients with } \\
\text { erythema nodosum leprosum } \\
(\mathbf{n}=13)\end{array}$ & $\begin{array}{c}\text { Patients with } \\
\text { arthritis } \\
(\mathbf{n}=20)\end{array}$ & $\begin{array}{c}\text { Patients without } \\
\text { arthritis } \\
(\mathbf{n}=33)\end{array}$ \\
\hline $1 / 32$ & 2 & $4(3: 1)$ & 5 \\
$1 / 64$ & $1+$ & $1(0: 1)$ & 7 \\
$1 / 128$ & 1 & $3(3: 0)$ & 1 \\
$1 / 1024$ & 4 & $8(6: 2)$ & 22 \\
\hline Total positive & 9 & $12(5: 7)$ & 11 \\
Total negative & & & \\
\hline
\end{tabular}

$\star$ Patients with radiological erosions:patients without radiological erosions in parentheses.

†Patient with radiological erosions.

arthritis slowly resolved and the morning stiffness and joint pain improved. Joints were less swollen with resolution of joint effusions and a reduction of the Ritchie articular index. Whether this was due to the reintroducion of treatment or part of the natural progress of the arthritis was unclear.

Acute and chronic arthritis associated with erythema nodosum and leprosum reactions is well documented. ${ }^{3.5}$ It may represent an "Arthus" reaction or a reactive arthropathy ${ }^{17}$ and is restricted to the lepromatous end of the range of leprosy. In contrast, the arthritis we report here was of gradual onset, encompassed the whole range of leprosy, and had no other clinical features of erythema nodosum leprosum.

IgM rheumatoid factor is often found in people in tropical regions and in patients with leprosy ${ }^{18-22}$ but in this study was found more commonly in those patients without arthritis. Coincidental leprosy and rheumatoid arthritis in these patients was unlikely because of the large number of patients affected, the high proportion of men, and the lack of extra-articular manifestations of rheumatoid arthritis.

Acute phase proteins are stimulated as part of the non-specific host defence mechanism. They bind and transport potentially damaging enzymes released at the site of tissue destruction regardless of the exciting cause. ${ }^{23}$ C Reactive protein concentrations were significantly raised in the patients with arthritis, which mirrors the rise in concentration found in patients with any chronic inflammatory disease affecting the synovial joint. ${ }^{24} \mathrm{C}$ Reactive protein concentrations may rise steeply after destruction of tissue by bacteria but not by viruses or a non-specific inflammatory stimulus, ${ }^{25}$ and therefore the chronic relapsing erosive arthritis reported here may be due directly to $M$ leprae.

Lepra cells have been decribed in the joint cavity, ${ }^{26}$ and leprosy is analogous in many ways to rheumatoid arthritis. ${ }^{27}$ Reports have suggested a disturbance in the lymphoproliferative, ${ }^{28}$ skin test, ${ }^{29}$ and antibody responses $^{30}$ to crude mycobacterial antigens in rheumatoid arthritis. Cells exposed to heat, toxins, or oxygen reduction products produce heat shock proteins, which may be essential for cell survival. ${ }^{31}$ Patients with rheumatoid arthritis have significantly raised titres of IgG and IgA binding to a 65 kilodalton mycobacterial heat shock protein. Binding to this mycobacterial antigen was reported to be greater than that seen in tuberculosis. ${ }^{31}$ Titres of agalactosyl IgG molecules are raised in rheumatoid arthritis and $M$ tuberculosis infection but not in other diseases investigated. ${ }^{31}$ Both these factors may be relevant to the initiation and development of an arthritis by $M$ leprae. This arthritis requires further study with a systematic survey of patients with leprosy and patients with rheumatoid arthritis, both within and between communities.

We thank Drs J M Constable and I D Griffiths, of the Royal Victoria Infirmary, Newcastle upon Tyne, for their support and advice. This study was supported by the British Leprosy Association (LEPRA) and the Arthritis and Rheumatism Council (Great Britain).

1 Ridley DS, Jopling WH. Classification of leprosy according to immunity: a five group system. International fournal of Leprosy 1966;34:255-73.

2 Jopling WH. Handbook of leprosy. London: Heinemann, 1971:3-33.

3 Karat ABA, Karat S, Job CK. Acute exudative arthritis in leprosy: rheumatoidarthritis like syndrome in association with erythema nodosum leprosum. BrMed F 1966;iii:770-3.

4 Ramu G, Balakrishnan S. Arthritis in lepromatous leprosy: clinical features and biochemical findings. Leprosy in India 1968;2:1-8.

5 Ramu G, Ramanujam K. Reactive states in lepromatous leprosy. A study Ramu $G$, Ramanujam K. Reactive states in lepromatous leprosy. A study
from the clinical and bacteriological aspects. Leprosy in India 1964;36:3-19.

6 Lele RC, Sainani GS, Sharma KD. Leprosy presenting as rheumatoid arthritis. I Assoc Physicians India 1965;13:275.
.

7 Medi TH, Lele RC. Acute joint manifestations in leprosy. $\mathcal{F}$ Assoc Physicians India 1969;17:247.

8 Atkin SL, Welbury RR, Stanfield E, Beavis D, Iwais B, Dick WC. Clinical and laboratory studies of inflammatory polyarthritis in leprosy patients in Papua New Guinea. Ann Rheum Dis 1987;46:688-90.

9 Wright V. Relationship between ankylosing spondylitis and other spondarthritides. In: Moll JMA, ed. Ankylosing spondylitis. London: Churchill Livingstone, 1980:42-52.

10 Levy J, Dick WC. Detection of change in disease activity in patients with rheumatoid arthritis. In: Clinics in the rheumatic diseases. London: Saunders, 1976:225-43.

11 Ritchie DM, Boyle JA, McInnes JM, et al. Clinical studies with an articular index for the assessment of joint tenderness in patients with rheumatoid arthritis. Qf Med 1968;37:393-406.

12 Waaler $\mathrm{E}$. On the occurrence of a factor in human serum activating the specific agglutination of sheep red corpuscles. Acta Pathologica et Microbiologica agglutination of sheep red
Scandinavica 1940;17:172-8.

13 Deaton CD, Maxwell KW, Smith RS, Crevelling RL. Use of laser nephelometry in the measurement of serum proteins. Clin Chem 1975;22:1465-9.

14 Rubinstein KE, Schneider RS, Ullman EF. Homogeneous enzyme immunoassay: a new immunochemical technique. Biochem Biophys Res Commun 1972;47:846-51

15 Nie NH, Hull CH, Jenkins JG, Steinbrenner K, Bent DH. Statistical package for the social sciences. New York: McGraw-Hill, 1975.

16 Karat S, Karat ABA, Foster R. Radiological changes in bones of the limbs in leprosy. Lepr Rev 1968;39:147-69.

17 Sharma VK, Saha K, Sehgal VN. Serum immunoglobulins and autoantibodies during and after erythema nodosum leprosum (ENL). Int $f$ Lepr Other Myobact Dis 1982;50:159-63.

18 Greenwood BM, Herrick EM. Low incidence of rheumatoid factor and autoantibodies in Nigerian patients with rheumatoid arthritis. Br Med $\mathcal{F}$ 1970;i:71-3.

19 Gonzales-Pares EN, Franco AE, De La Cruz S, Molares FR, Gonzales-Alcover $\mathrm{R}$, Bryan RM. False positive latex in a tropical area. $\mathcal{F}$ Chronic Dis 1973;26:31-8.

20 Toh BH, Sengupta S, Ang AH, White JC, Lav KS. Pattern of rheumatoid arthritis in West Malaya. Ann Rheum Dis 1973;32:151-6.

21 McGregor IA. Immunity and malaria in man. Trop Doct 1974;4:104-9.

22 Cathcart ES, Williams RC, Ross SH, et al. The relationship of the latex fixation test to the clinical and serological manifestations of leprosy. $\mathrm{Am} \mathcal{J} \mathrm{Med}$ 1962;56:545-52

23 Koj A. Acute phase reactants. In: Allison AC, ed. Structure and function of plasma proteins. London: Plenum Press, 1974:73-125.

24 Carr W. Acute phase proteins. In: Jeffrey MS, Dick WC, eds. The role of the laboratory. London: Saunders, 1983:227-339.

25 Becker GJ, Walberg M, Hughes GRV, Pepys MB. Value of C-reactive protein measurement in the investigation of fever in systemic lupus erythematosus. Ann Rheum Dis 1980;39:50-2.

26 Louie JS, Koransky JR, Cohen AH. Lepra cells in synovial fluid of a patient with erythema nodosum leprosum. N Engl f Med 1973;289:1410.

27 Panayi GS. Viewpoint: does rheumatoid arthritis have clinicopathological aetiology similar to leprosy. Ann Rheum Dis 1982;41:102-3.

28 Holoshitz J, Klajaman A, Drucker J, et al. T-lymphocytes of rheumatoid arthritis patients show augmented reactivity to a fraction of mycobacteria cross-reactive with mycobacteria. Lancet 1986;ii:305-9.

29 Bahr GM, Stanford JL, Sattar I, et al. HLA-DR and tuberculin tests in rheumatoid arthritis and tuberculosis. Ann Rheum Dis 1989;48:63-8.

30 Bahr GM, Rook GAW, Shahin A, Stanford JL, Sattar MA, Behbehani K. HLA-DR associated isotype-specific regulation of antibody levels to mycobacteria in rheumatoid arthritis. Clin Exp Immunol 1988;72:26.

31 Rook GAW. Rheumatoid arthritis mycobacterial antigens and agalactosyl IgG. Scand I Immunol 1988;28:487-93.

(Accepted 20 March 1989) 